\title{
A REVIEW DYNAMIC VIBRATION ON DRILL STRING IN DRILLING OPERATION
}

\author{
Afriansyah $^{1)}$ dan Hasan Basri ${ }^{2)}$ \\ 1,2 Departmen of Mechanical Engineering Sriwijaya University \\ 1,2 Jalan Srijaya Negara, Palembang, 30139 \\ E-mail: afri.praboe@gmail.com ${ }^{1)}$, hasan_basri@unsri.ac.id ${ }^{2)}$
}

\begin{abstract}
For decades, researchers have investigated the phenomenon of vibrations in drilling activities. One of the interesting things is the vibration in the drillstring. Vibration might be caused by Interfere with each other between the drilling mud and drilling string, contact forces between the drillstring and wellbore, and interfere with each other between bit and wellbore that can ruin the drilling equipment, the drillstring and/or the stabilizers. This paper presents several experiments in different methods to predict vibrations of drill string in the drilling operation. There are three types of vibration in drilling operation. First, axial vibration generated from interaction between bottom hole and bit. Second, Torsional vibration that excited from resonance of drill collar, bit chatter, stick slip between formation and bit and modal coupling. Third, lateral vibration that excited from interaction between formation and bit, imbalance of mass, whirl of bit, and from force of fluid around drill string. One or whole type of these vibration can vibrate the drillstring and it result damage of drillstring as reperesent by decrease in rate of penetration or damage of bit. In this paper, we will compare several methods to predict deflection, natural frequencies, and trajectory or orbital during impact for finite element method, differential quadrature method, and multibody dynamic method. Result show that all method can be used for calculating deflection, Finite element method and differential quadrature method for account natural frequencies, multi dynamic method for calculate trajectory during impact. However, for simple method to calculate or predict vibration used Differential Quadrature method. The future work will involve investigation on vibration in drillstring with combine several method
\end{abstract}

Keywords: Drillstring, Vibration Analysis, Axial Vibration, Torsional Vibration, Lateral Vibration.

\section{INTRODUCTION}

Better penetrating strategy has improved for decade, because of high necessity for oil and gas industry. Their targets are keep away from and decline default with the goal that decline cost and contamination's by discarding substitution-drilling hardware, Re-entry drilling, and unscheduled disappointment of gear, effect of vibration because of high revolution of drill-string and shake arrangement or peripheral water and drilling liquids.

Basicly, drilling system in drilling technology are consist of lifting and rotating mechanism (such as drawwork, travelling block, top drive or Kelly, rotary tables, etc.), drillpipe, bottom hole assembly (such as drill collar, heavy weight drill pipe, stabilizer), bit (such PDC or Tricone bit). Drillcollar are thick-walled pipes. It used for weighting bit to supply weight on bit (WOB) and avoid drillpipes from bending by tension drill pipes at neutral point. Stabilizer (centralizers) are attached between two drill collar and upon at bit, performed string in the center of wall (borehole). It part of bottom hole assembly (BHA). Stabilizers have a large diameter, which is small clearance with borehole, and have a short length. Stabilizers also increase bit productivity (bit hours) by avoiding buckling at drill collar lower part. Drillstring components from drillpipe (top), stabilizer, a string of drill collar, stabilizer, BHA, and a bit. Vibration might be caused by Interfere with each other between the drilling mud and drilling string, contact forces between the drillstring and wellbore, and interfere with each other between bit and wellbore that can ruin the drilling equipment, the drillstring and/or the stabilizers.

Basicly, there are three types of vibration in drilling operation (Ghasemloonia et al, 2015). First, axial vibration that excited from interaction between bottom hole and bit. This should generate irregular of WOB and suspended particulate phase SPP, inconsistent rate of penetration (ROP), bouncing of surface equipment at surface drilling depths, loss of tool face and uncontrol directional tool. Second, Torsional vibration that excited from resonance of drill collar, bit chatter, stick slip between formation and bit and modal coupling. Uncontrol movement of stick - slip may even reason a switching of bit heading and another condition ceasing it. Third, lateral vibration that excited from interaction between formation and bit, imbalance of mass, whirl of bit, and from force of fluid around drill string. Lateral vibration also generate from interaction between axial and lateral directions and appearance of axial bit-bounce motion.

One or whole type of these vibration can vibrate the drillstring and it result damage of drillstring as represent by decrease in rate of penetration or damage of bit. Low dimensional models and Finite Element can be used to 
predict vibration on drillstring like stick-slip oscillation (Kapitaniak et al., 2015).

For longitudinal vibration on drillstring, lateral inertia effect can be used as a models and Laplace Transform is used for complex impedance solution (Tian et al., 2016). Relation between ROP, Weight on Bit (WOB), rotational speed, and depth of cut can be describe with analytical bit response. Result showed axial vibration also increase as torsional torque increase ((Bavadiya et al., 2017). Stick-slip interaction between bit and rock can be describe as dynamic two-degree freedom models (Alqaradawi at.al, 2018). Nonlinear interaction between various vibrations like whirling vibration, axial and torsional oscillation. Low dimensional models can be used to study drilling stability based on stick slip and bit bounce (Wiercigroch et al., 2018).

\section{FOCUS AND SCOPE}

In this research, the problem includes:

1. The scope of the problem.

The problems discussed in this research only focus on phenomena that occur on the vibration of drillstring on when drilling operations

2. The limitations of the research

Limitations of this research issue only focus on the results of the comparison between the finite element method, differential quadrature method, multibody dynamic method, string-borehole interaction method

3. Plan the results obtained

The expected results obtained are able to know the deflection occurred comparative, natural frequencies, and trajectory during impact for each method

\section{MATERIAL AND METHOD}

There are several method for study vibration on drillstring that has been done by researcher. Most of the researcher focus on partial part or equipment models of overall drilling rig. Partial system models represent entire condition. It known as boundary condition. We can use these models for describe measurement damage of drillstring that caused by vibration. Generally, they focused on torsional and lateral vibration. In this paper, we compare three method for calculated vibration on drillstring: Finite element, Differential Quadrature, and multibody dynamic.

\subsection{Finite Element Method}

In this paper, the author describe a finite elements modelling of the entire elastic drill string such as drill pipe and drill collar based on experiments of Y.A Khulief. Model in this experiment include effect of gravitational stiffening and associated compression and tension fields within the drillstring due to the torsional bending inertia coupling and gyroscopic effect. For formulation, the author assumed that the drillstring material is elastic, isotropic, and homogeneous.

The finite element model used the drillstring in vertical and rotational operation (Figure 1). They used
Cartesian diagram to explain orientation and angle of force in drill string

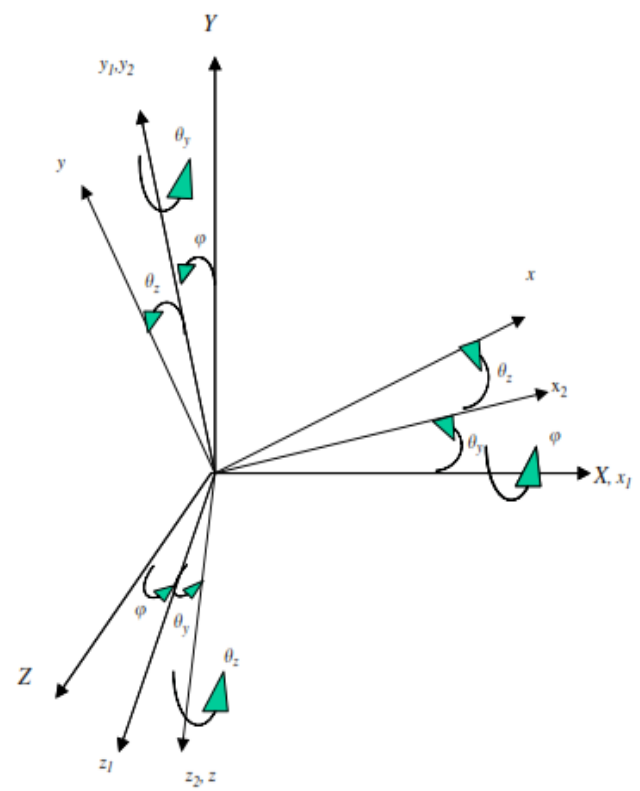

Figure 1 Coordinate System

The equation of models used finite element method based on lagrangian approach. With finite element, drillstring divided into 12 degrees of freedom as a finite shaft element. The model calculates for the effect of the gravitational force field, the torsional/bending inertia coupling, and the gyroscopic effect. A consistent mass formulation use to derive explicit expressions of the axial stiffening matrices and the finite element of inertia coupling. Modal transformations are address to determine a reduced order modal form of the dynamic equations. A computational scheme integrated the developed models to make time-response analysis of the drillstring system and to account the modal characteristics.

\subsection{Differential Quadrature Method}

This method shows to predicting vibrations from drillstring in close of straight hole based on experiment by H. Hakimi. First, calculate the effective length of drillstring that lean on the wall of borehole with a nonlinear static analysis. For formulate the string, used exact form of beam curvature. For contact between drillstring and borehole wall in different size, used a model a series of spring. Considered it located through its length. Then applied DQM to the equations of nonlinear differential from drillstring sections. After that, assign boundary condition from equation. To solve the system of nonlinear equations used The NewtonRaphson algorithm. Next, determine the drillstring natural frequencies with analysis of a free vibration. Calculate lateral natural frequencies with Free vibration analysis using effective length obtained from static analysis, while torsional and axial natural frequencies is 
calculated based on the full length of the string. From a progression of contextual investigations, the numerical outcomes got. It confirm the exactness and value of the method in managing issues of drillstring vibration.

The author used DQM instead of FEM because it have two favourable circumstances while considering the DQM with FEM: (1) less difficult calculations and subsequently less demanding execution; (2) more efficient arrangement by requiring less discretizing focuses.

\subsection{Multibody Dynamic Method}

In this method describe phenomena in interaction in drilling system include drillstring and drilling fluid with a multibody dynamic model based on experiment $\mathrm{Ma}$ Yanhui's. The drillstring is a coupling system with complex rigid-flexible, including constraints and dynamic loads, Euler-Bernoulli beam elements, rigid bodies, and model of dynamic system. For determine dynamic model, used formulation from the absolute nodal coordinate. Around of wall and drillstring consist of drilling fluid which covered annulus, below bit, and internal of drillstring. The drilling fluid modelled as onedimensional compressible fluid (figure 2), the Arbitrary Lagrangian-Eulerian description is use for model of the relative flow of the drilling fluid, the drillstring force following up on the drilling fluid is presented through the drilling fluid transport movement. In the meantime, the response force working on the drillstring is taken as an external load. Based on Hertz contact theory, they simulated the contact between the drilling fluid and drillstring, and based on the rock-breaking velocity equation, they built the rock penetration models. Based on this model, the impact of the drilling fluid flow rate and density and the coupled vibration of the drillstring on the drilling process are examined through a few precedents.

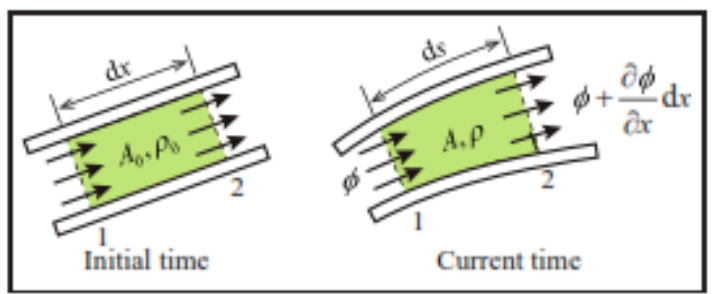

Figure 2. The fluid mass conservation schematic

\section{DISCUSSION}

This section describes the result following each researcher as mentioned above which is used several methods to obtain vibration in drillstring during drilling operation.

The result from Khulief experiment's, that first, they determine drillstring component include drill collar and drill pipe into dynamic model and formulate it. Then they considered drillstring into elastic, homogeneous, and isotropic. After that, they used FEM models in rotational vertical operation with Cartesian coordinate system. Equation of motion is used with Lagrange equation. It's applying strain energy of the finite drillstring element and kinetic energy of the finite drillstring element. Modal transformations is used to a reduced order modal form of the dynamic equations.For drill string specification as shown in Tabel 1.

Tabel 1. Drill string configuration

Drill pipe Specification

Drillpipe length $(\mathbf{L p})$

Drillpipe outer diameter (Do)

$1000 \mathrm{~m}$

Drillpipe indide diameter (Di)

$0.127 \mathrm{~m}$

$0.095 \mathrm{~m}$

Drillcollar specification
Drillcollar length (Dc)

Drillcollar outer diameter (Do)

$200 \mathrm{~m}$

Drillcollar inside diameter (Di)

$0.2286 \mathrm{~m}$

$0.0762 \mathrm{~m}$

Material specification

Drillstring density ( $\rho)$

Modulus of elasticity (E)

Shear modulus (G)

$7850 \mathrm{~kg} / \mathrm{m}^{3}$

$210 \times 10^{9} \mathrm{~N} / \mathrm{m}^{2}$

$7.6923 \times 10^{10} \mathrm{~N} / \mathrm{m}^{2}$

For numerical result, they used Matlab $^{\mathrm{TM}}$ to computational scheme. The results from this method based on finite element method formulation. The elements have 25 nodes and connected by 24 equal finite shaft elements, each node has two bending rotations, two translations, one torsional and one axial (6 degrees of freedom). After applying the boundary conditions for the drillstring system, A total of 140 degrees of freedom is restrain.

From modal analysis, they determined variance effect of the Weight on Bit (WOB) include neutral point (NP) location on the first two bending frequencies (Figure 3$6)$. it is note that there are relation between drillstring rotation and natural frequencies. When drillstring rotations tend to increase, the forward natural frequencies tend to increases. Contrasts of that, the backward natural frequencies tend to lower of that. This behaviour is comparative with rotodynamic observations.

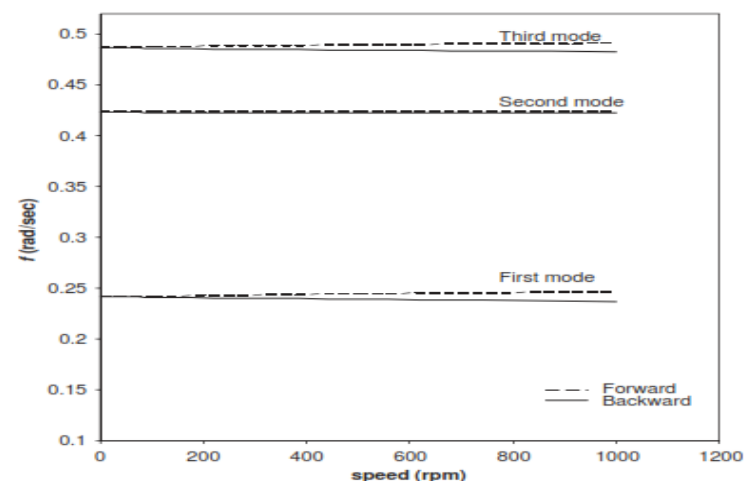

Figure 3 Frequency of bending located at the bottom of neutral point. 


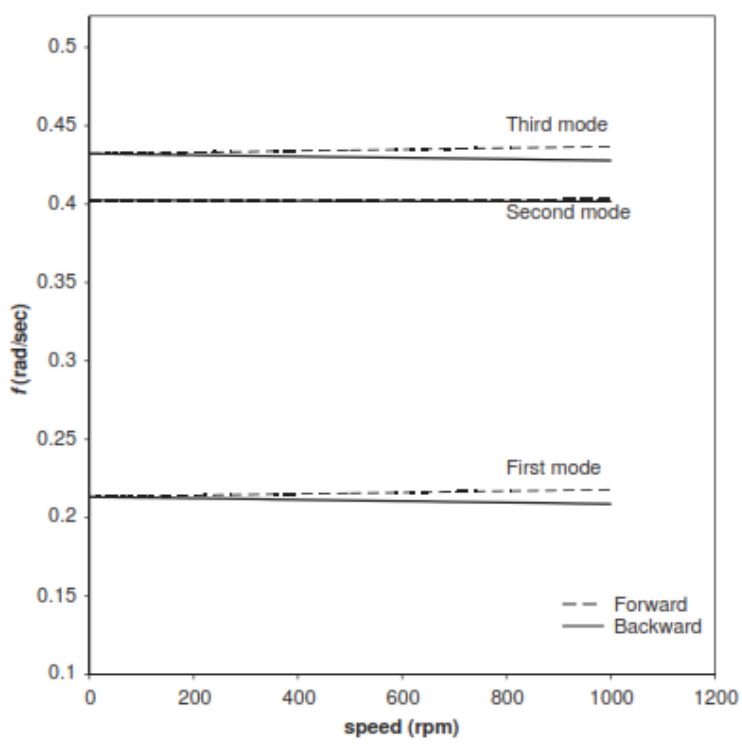

Figure 4 Frequency of bending located at $100 \mathrm{~m}$ over the base for neutral point.

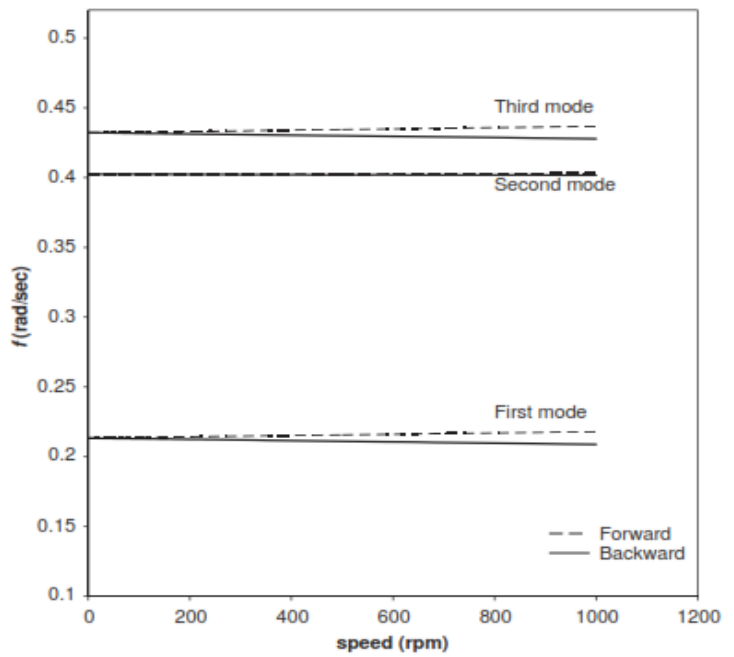

Figure 5 Frequency of bending located at $200 \mathrm{~m}$ over the base for neutral point

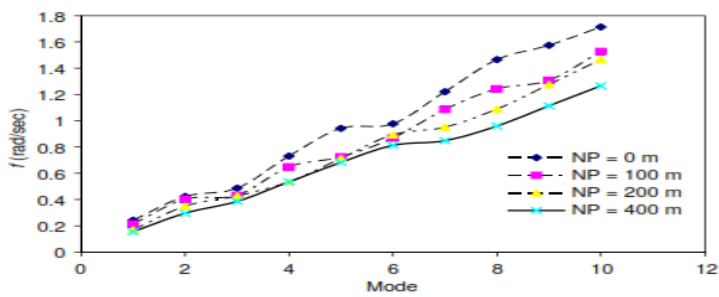

Figure 6 The first ten bending modes frequencies for various location of neutral point (NP).

In analysis of dynamic response, the response of drillstring transient is known for two different excitations: applied impulse force and initial displacement. For initial displacement, they computing the displacement of nodal from the static defection equation and employing a force at roughly halfway of drill pipe. Response of dynamic from node 3 showed 5
Degree of freedom (DOF) reduce order models gives a good response to that of 140 Degree of freedom (DOF) full order models (Figure 7)

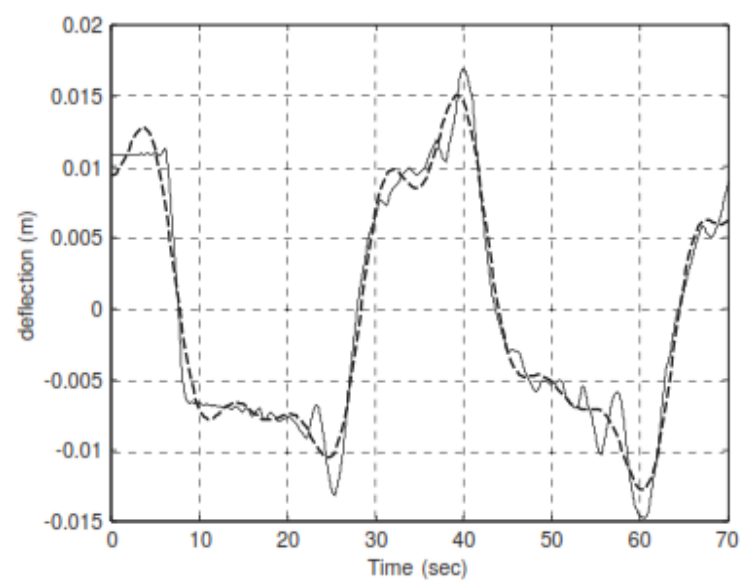

Figure 7 response of Transient from node 3 for ((- - -) for reduced order) and initial displacement input

$$
((-) \text { for full order }
$$

It is known that forces of impulsive likely to generate higher frequencies, thus involving higher modes to share an obvious measure of the system's kinetic energy. Therefore, for significant models of the reduced-order model are enlarged. For more preferable result and more appropriate, the 8-DOF is better than 5-DOF reduced order models (Figure 7 and 8).

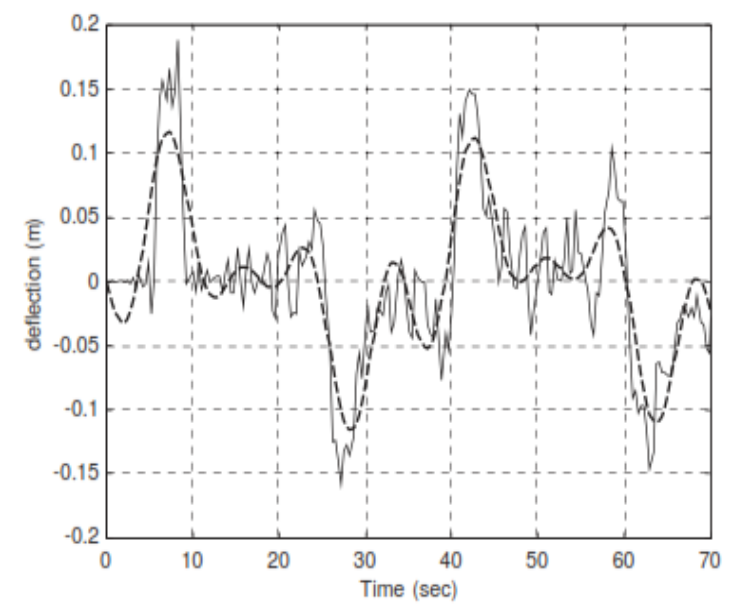

Figure 8 response of Transient from node 3 for ( - - ) for reduced order). For 5 DOF and initial velocity ((-) for full order)

Based on Hakimi experiment's, for analyze nonlinear vibration on drillstring used Differential Quadrature Models (DQM). It useful to calculate an effective length of string that lean on the borehole wall. To formulate it, the author considered as a beam curvature. Then DQM discretized resulting nonlinear differential equation system and Newton-Raphson algorithm solves it. Next, DQM performed analysis of free vibration to account the drillstring natural frequencies. 
A drillstring, which used in this paper based on burges et al. (1987). The drillstring is listed in table 2.The well angle from vertical direction by $1^{\circ}$ and the weight on bit was recorded at $15 \mathrm{klb}(66.7 \mathrm{kN})$.

Table 2. Drillstring configuration and material properties

\begin{tabular}{cccc}
\hline Tools & Length $(\mathbf{m})$ & O.D in $(\mathbf{m m})$ & I.D in (mm) \\
\hline Drill Pipe & 37.2 & $3.5(88.9)$ & $2.06(52.3)$ \\
$\quad$ Drill & 161.3 & $4.75(120.7)$ & $2.25(57.2)$ \\
Collar & & & \\
Stabilizer* & 2 & $4.75(120.7)$ & $2.25(57.2)$ \\
Drill Collar & 9.4 & $4.75(120.7)$ & $2.25(57.2)$ \\
Stabilizer* & 1.95 & $4.75(120.7)$ & $2.25(57.2)$ \\
Bit & 1 & $6.25 \quad 158.8)$ & 0 \\
\hline & *Blade O.D is $158.8 \mathrm{~mm}$ &
\end{tabular}

\begin{tabular}{cc}
\hline Drillstring & \\
Modulus Elasticity (E) & $214 \times 10^{9} \mathrm{~N} \cdot \mathrm{m}^{-2}$ \\
Mass density (p) & $7850 \mathrm{~kg} \cdot \mathrm{m}^{-3}$ \\
Shear Modulus (G) & $82 \times 10^{9} \mathrm{~N} \cdot \mathrm{m}^{-2}$ \\
Formation & \\
Stiffness (K) & $100 \times 10^{5} \mathrm{~N} \cdot \mathrm{m}^{-1}$ \\
\hline
\end{tabular}

To find effective length of drillstring, analysis of nonlinear static was conducted by newton-raphson algorithm. Figure 9 shows drillstring in deflected condition where most of its length leans on the borehole wall. The points have zero deflection correspond to rotary table, the two stabilizers and bit. The point at 109 $\mathrm{ft}(33.2 \mathrm{~m})$ from the bit is found the string contacts the formation.

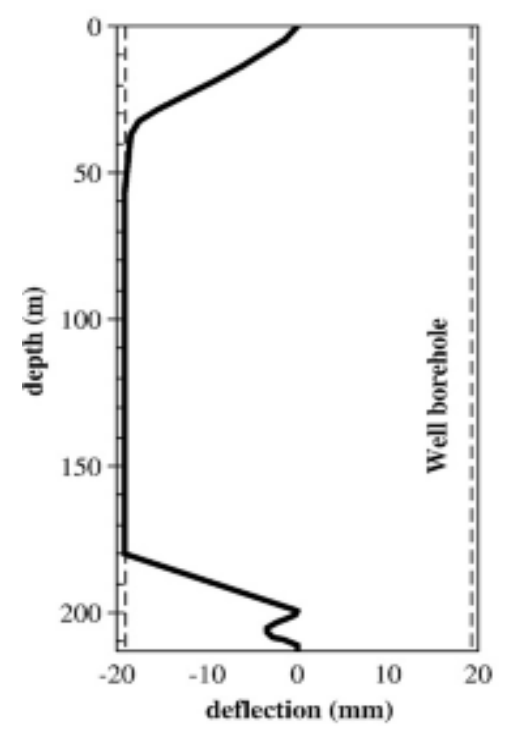

Figure 9 Drillstring deflection under static load.

The result of natural frequencies, which compared with burges et al (1987) in Table 3. As can be shown from the Figure 10, the results from Differential Quadrature Method (DQM) have similar with finite element method from Burges et al.
Table 3 Result between DQM and Burges

\begin{tabular}{ccc}
\hline & $\begin{array}{c}\text { First Frequency } \\
(\mathbf{H z})\end{array}$ & $\begin{array}{c}\text { Second } \\
\text { Frequency }(\mathbf{H z})\end{array}$ \\
\hline DQM & 1.24 & 3.16 \\
Burges et.al & 1.25 & 3.15 \\
\hline
\end{tabular}

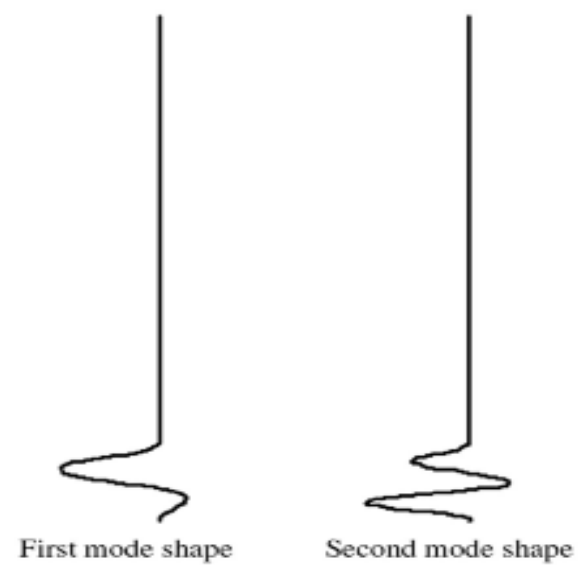

Figure 10. Results for lateral natural frequencies and Lateral modal shapes of drillstring.

For validate this method, they re-evaluate case study from jogi, et.al (2002). The drillstring length is $526.8 \mathrm{ft}$ $(160.6 \mathrm{~m})$, the weight on bit was recorded at $25 \mathrm{klb}$ $(115.7 \mathrm{kN})$, and the well deviated by $1^{\circ}$ from the vertical direction. They compare result with commercial software like NATFREQ, BHASYS, NADRID and WHIRL. Result DQM of static analysis, they found the string effective length was calculated to be $181 \mathrm{ft}(55.2 \mathrm{~m})$. Table $4-6$ show the comparison of the measured natural frequencies with the results evaluated by BHASYS, DQM, NADRID, WHIRL and NATFREQ. Result from the tables, we can found there is a similarity between DQM result and the other method.

Table 4. Comparison of measured and modelderived axial resonant frequencies

\begin{tabular}{cccccc} 
Mode & Measured & $\begin{array}{c}\text { DQM } \\
(\mathbf{H z})\end{array}$ & $\begin{array}{c}\text { BHASYS } \\
(\mathbf{H z})\end{array}$ & $\begin{array}{c}\text { NATFREQ } \\
(\mathbf{H z})\end{array}$ & $\begin{array}{c}\text { WHIRL } \\
(\mathbf{H z})\end{array}$ \\
\hline $\mathbf{1}$ & 9.7 & 9.78 & 9.06 & 8.7 & 8.53 \\
$\mathbf{2}$ & 26.3 & 27.67 & 26.01 & 25.4 & 24.86 \\
$\mathbf{3}$ & 40.3 & 41.29 & 40.74 & 40.1 & 39.43 \\
\hline
\end{tabular}

Table 5. Comparison of measured and model-derived torsional resonant frequencies.

\begin{tabular}{cccccc}
\hline Mode & Measured & $\begin{array}{c}\text { DQM } \\
(\mathbf{H z})\end{array}$ & $\begin{array}{c}\text { BHASYS } \\
(\mathbf{H z})\end{array}$ & $\begin{array}{c}\text { NATFREQ } \\
(\mathbf{H z})\end{array}$ & $\begin{array}{c}\text { WHIRL } \\
(\mathbf{H z})\end{array}$ \\
\hline $\mathbf{1}$ & 5.0 & 3.61 & 1.3 & 3.8 & 3.83 \\
$\mathbf{2}$ & 14.4 & 12.57 & 9.44 & 13.46 & 13.61 \\
$\mathbf{3}$ & 23.5 & 23.58 & 20.71 & 24.53 & 24.82 \\
\hline
\end{tabular}


Table 6. Comparison of measured and model-derived lateral resonant frequencies.

\begin{tabular}{cccccc}
\hline Mode & Measured & $\begin{array}{c}\text { DQM } \\
(\mathbf{H z})\end{array}$ & $\begin{array}{c}\text { BHASYS } \\
(\mathbf{H z})\end{array}$ & $\begin{array}{c}\text { NATFREQ } \\
(\mathbf{H z})\end{array}$ & $\begin{array}{c}\text { WHIRL } \\
(\mathbf{H z})\end{array}$ \\
\hline $\mathbf{1}$ & 1.3 & 1.28 & 1.3 & 1.67 & 1.21 \\
$\mathbf{2}$ & 2.01 & 1.92 & 2.05 & - & 2.03 \\
$\mathbf{3}$ & 2.57 & 3.44 & 2.51 & 2.49 & 2.54 \\
\hline
\end{tabular}

Based on experiments from Yanhui, a model of simulation used the multibody dynamic approach based on the coupling of drillstring and drilling fluid. According to this models, drilling fluids is modelled using ALE (Arbitrary Lagrangian-Eulerian) method, for drillstring, assumed as ANCF (Absolute Nodal Coordinate Formulation) beam with a few contact detection points, Hertz contact theory used for contact between wellbore and drillstring. Also considered rock penetration process, so this model can be used for simulation of couple vibration and drillstring process with suppression on drilling fluid effect.

Parameter of drillstring can be seen in Table 7. from drilling parameters, wellbore assumed as vertical wellbore with depth $2000 \mathrm{~m}$, rotational speed of top drive around $80 \mathrm{rpm}$. Drillstring divided into 225 element through mesh convergence test, and amount of internal element and annulus fluids is same or equal to drillstring.

Table 7. The system analytical parameters.

\begin{tabular}{llcc}
\hline Subsystem & Parameter & Value & Unit \\
\hline Drillstring & Elastic modulus & 210 & $\mathrm{GPa}$ \\
& Density & 7850 & $\mathrm{Kg} / \mathrm{m}^{3}$ \\
\multirow{3}{*}{ Drilling fluid } & Poisson's ratio & 0.28 & \\
& Flow rate & 30 & $\mathrm{~L} / \mathrm{s}$ \\
& Density & 1350 & $\mathrm{Kg} / \mathrm{M}^{3}$ \\
& Q 600 & 100 & \\
& Q 300 & 60 & \\
Contact & Stiffness & $1 \times 10^{8}$ & $\mathrm{~N} / \mathrm{m}$ \\
& Damping & $1 \times 10^{3}$ & $\mathrm{~N} \mathrm{~s} / \mathrm{m}$ \\
& Friction coeff & 0.0005 & \\
\hline
\end{tabular}

Bit pressure caused axial vibration. Figure 11 shows two models of bit pressure. Result of fluctuation bit pressure is closed to periodic fluctuation and discrepancy of two models is not clear.

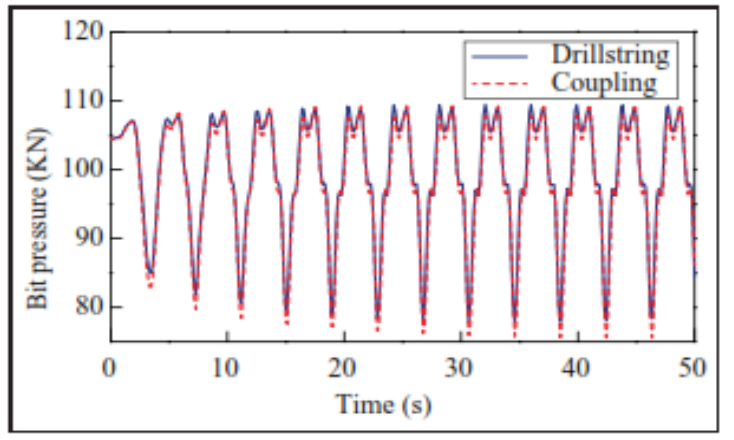

Figure 11 The two models of bit pressure

Friction between wellbore and drillstring caused torsional vibration. The speed of bit is $0-2$ times of top drive when the driver rotated at constant speed. Figure 12 shows a curve of bit speed from 2 models.

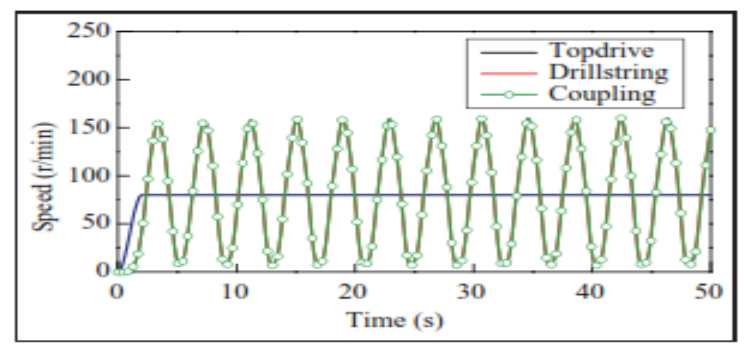

Figure 12 The result bit speed

One of the vibrations in typical transverse is whiling motion. String revolved around the axis of borehole and rotate on its axial axis might be imbalance mass or other disruption force. Figure 13(a) and 14(a) show drillstring deformation at the end of the simulation, and Figure 13(b)-(d) and 14(b)-(d) show drillstring center whirl orbit with depth measurement at 600,1200 and 1900m.

Due to lower part of drilling string receive compressions forces, so whirling motion are more simply to compare with upper part of it. Based on system dynamic response, whirling motion from coupling model take place at constant rotary speed and have a large deformation in drillstring. Otherwise, drillstring position still in center to the borehole when drilling fluid is neglected. Special note, there is helical deformation when model of coupling collar and outer part of collar against the borehole well.

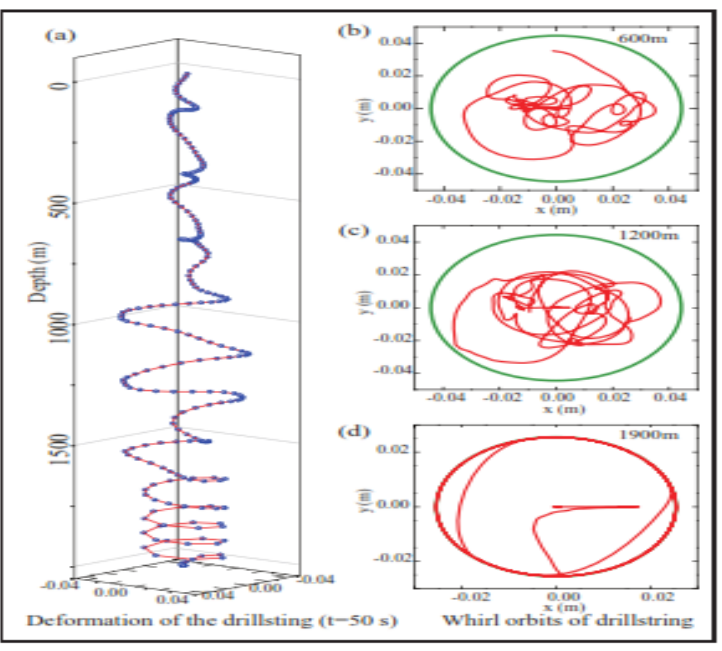

Figure 13 Motion of Whirling from model of coupling

(a) deformation of Drillstring $(t=50 \mathrm{~s})$. (b-d) drillstring Whirl orbits. 


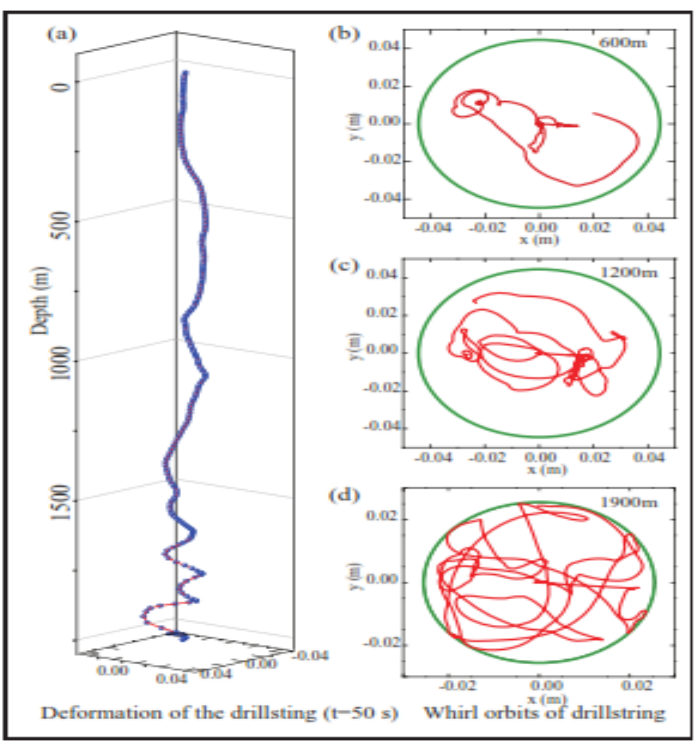

Figure 14 Motion of Whirling from the model of drillstring (a) Drillstring deformation $(t=50 s)$. (b-d) drillstring Whirl orbits.

The simulation models compare angle of inclination and well trajectory with variance flow rate for effect of drilling fluids on drilling process. Figure 15 and 16 show result that lower flow rate in well trajectory system is similar with no drilling fluid in system. When fluid rate rise, difference become increase.

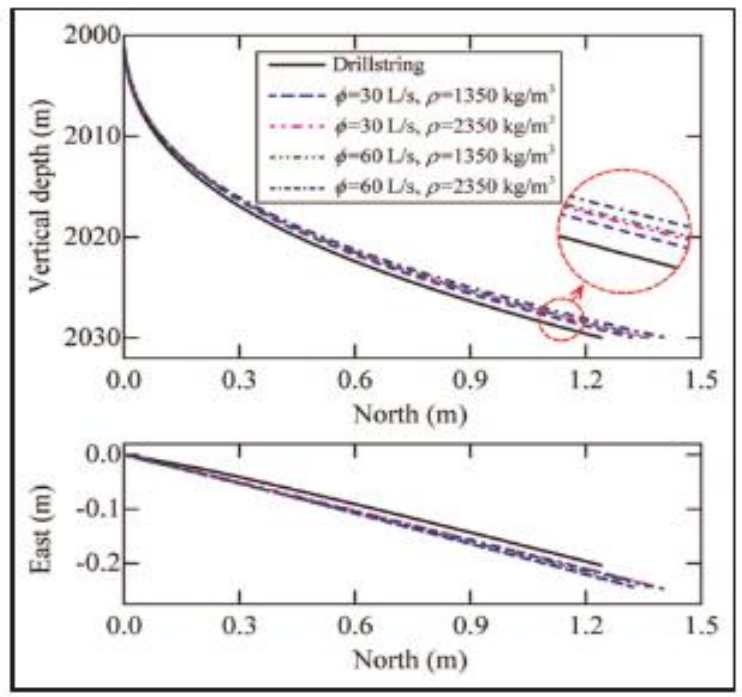

Figure 15 The system well trajectory with variance parameters of drilling fluid.

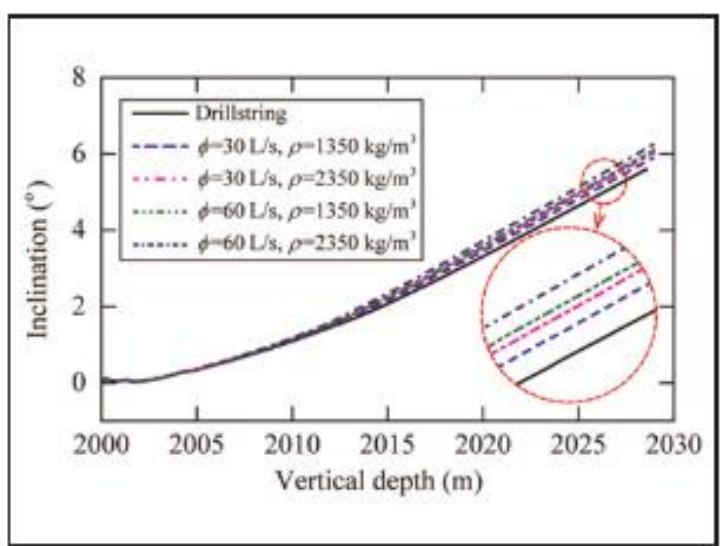

Figure 16 The system inclination angle with variance parameter drilling fluid.

Besides that, angle of inclination raise with density of drilling fluid is increase too, especially when flow rate of drilling fluid increases at same time.

For build-up rate, the result is increase in density drilling fluid and flow rate with increase in average of build-up rate.. but for whole subject, the density is less significant influenced than flow rate in the system.

Table 8 The average buildup rate of the simulation models.

\begin{tabular}{ccc}
\hline Flow rate $(\mathbf{L} / \mathbf{s})$ & Density $\left(\mathbf{k g} / \mathbf{m}^{\mathbf{3}}\right)$ & $\boldsymbol{\lambda}(\mathbf{0} / \mathbf{3 0 m})$ \\
\hline $\mathbf{0}$ & 0 & 5.594 \\
$\mathbf{3 0}$ & 1350 & 5.907 \\
$\mathbf{3 0}$ & 2350 & 6.034 \\
$\mathbf{6 0}$ & 1350 & 6.101 \\
$\mathbf{6 0}$ & 2350 & 6.251 \\
\hline
\end{tabular}

The average build up rate discrepancy between the model with $\left(\phi=30 \mathrm{~L} / \mathrm{s}, \rho=1350 \mathrm{~kg} / \mathrm{m}^{3}\right)$ and the model without drilling fluid is just $5.6 \%$. However, when the flow rate increases to $60 \mathrm{~L} / \mathrm{s}$, the discrepancy of two models is about $11.7 \%$, which conclude that the effect of the drilling fluid could not be ignored when drilling fluid flow rate become larger.

In order to make comparison between different method and achievement of deflection, Natural frequencies and trajectoryes, all result the experiment can be summarize as shown on Table 9 .

Tabel 9. Comparison several experiments result

\begin{tabular}{|l|c|c|c|}
\hline \multicolumn{1}{|c|}{ Methode } & Deflcetion & $\begin{array}{c}\text { Natural } \\
\text { frequencies } \\
\text { (rad/s) }\end{array}$ & $\begin{array}{c}\text { Trajectory } \\
\text { during } \\
\text { impact }\end{array}$ \\
\hline $\begin{array}{l}\text { Finite Element } \\
\text { method }\end{array}$ & $0.18 \mathrm{~m}$ & 1.7 & None \\
\hline $\begin{array}{l}\text { Differential } \\
\text { Quadrature } \\
\text { method }\end{array}$ & $0.2 \mathrm{~m}$ & $\begin{array}{c}10.05- \\
19.85\end{array}$ & None \\
\hline $\begin{array}{l}\text { Multi dynamic } \\
\text { method }\end{array}$ & $0.04 \mathrm{~m}$ & none & Show \\
\hline
\end{tabular}




\section{CONCLUSION}

For decades, researchers have investigated the phenomenon of vibrations in drilling activities. One of the interesting things is the vibration in the drillstring. This vibration consists of three types of vibrations whose result knows the natural frequency, deflection, trajectory and others. The aim is to reduce or eliminate the effects of vibrations that occur. To determine this, several methods are used, including the finite element method, differential quadrature, multi dynamic method, stick-slip method etc.

Based on three experiments above, we can use four method for calculating deflection on drillstring. For calculating natural frequency on drillstring, we can use finite element and differential quadrature method. For describe effect of deflection during impact, we can use multi dynamic method.

We may conclude that to know vibration in drillstring first we should determine dynamic equation to solve the problem. Then we can do some experiments to observe vibration on drillstring with boundary condition.

\section{SUGGESTION}

For calculating complex drillstring condition during operation such as drillpipe, BHA and drilling fluid we can use multibody dynamic model (Yanhui, Ma). For calculating natural frequencies in drill string, we can use Finite Element Mehode (Khulief) and Differential quadrature (Hakimi) method. For nonlinear analysis, we can used DQM (Hakimi) method.

For drillstring condition approach, we can use lagrangean approach and Finite elements method (Khulief), differential quadrature method (Hakimi), dynamic modelling (Yanhui). For simple method we can use DQM (diffrerential Quadrature Methode) from Hakimi.

The future work will involve investigation on vibration in drillstring with combine several method.

\section{REFERENCE}

Alqaradawi, M. Y., Kanzari, M. and Balachandran, B. 2018, Nonlinear stochastic drillstrings vibrations: Parametric study for stick-slip suppression, Journal of Physics: Conference Series, 1075(1). doi: 10.1088/1742-6596/1075/1/012059.

Bavadiya, V. A. et al. 2017, Experimental Investigation of the Effects of Rotational Speed and Weight on Bit on Drillstring Vibrations, Torque and Rate of Penetration. doi: 10.2118/188427-ms.

Ghasemloonia, A., Geoff Rideout, D. and Butt, S. D. 2015, A review of drillstring vibration modeling and suppression methods, Journal of Petroleum Science and Engineering. Elsevier, 131, pp. 150164. doi: 10.1016/j.petrol.2015.04.030.

Hakimi, H., and S. Moradi., Drillstring Vibration Analysis Using Differential Quadrature Method, Journal of Petroleum Science and Engineering 70 (3-4):235-42.

Kapitaniak, M. et al. 2015, Unveiling complexity of drill-string vibrations: Experiments and modelling, International Journal of Mechanical Sciences. Elsevier, 101-102, pp. 324-337. doi: 10.1016/j.ijmecsci.2015.07.008.

Khulief, Y. A., and H. Al-Naser, Finite Element Dynamic Analysis of Drillstrings, Finite Elements in Analysis and Design 41 (13): 1270-88.

Tian, J. et al. 2016, Mathematical Modeling and Analysis of Drill String Longitudinal Vibration with Lateral Inertia Effect, Shock and Vibration, 2016, pp. 1-8. doi: 10.1155/2016/6281264.

Wiercigroch, M. et al.2018), Complex dynamics of drillstrings: Theory and experiments, MATEC Web of Conferences, 211, p. 01002. doi: 10.1051/matecconf/201821101002. 